\title{
THE STUDY OF VOCABULARY SIZE OF SENIOR HIGH SCHOOL STUDENTS WHO PARTICIPATED IN ENGLISH DEBATE COMPETITION
}

\author{
Eka Sulistia Cahya \\ English Language Education Department \\ Halu Oleo University \\ E-mail : ekaekacahya@gmail.com
}

\begin{abstract}
This study was conducted to know whether there is any significant difference in vocabulary size between students who participated and those who did not participate in English debate competition. This study applied ex post facto design. The sample of this research was 30 students from 3 different schools, they were SMAN 2 Kendari, SMAN 4 Kendari, and SMAN 5 Kendari. The students were divided into two groups consist of 15 students. The researcher used the test of New Vocabulary Level Test (NVLT) to collect the data and the data were analyzed by using SPSS 16.0. The result showed that there is a significant difference of the mean score of the total correct answer that students could answer which automatically affect their amount of vocabulary size. The mean score of group 1 is 104 correct answer and it is higher than group 2 which gets the mean score of the correct answer only 82 . The significant value of $\operatorname{sig}(2$-tailed) is 0.001 ,

it is lower than $0.05(\operatorname{sig}(2$-tailed $)<\propto)$. It can be concluded that the alternative hypothesis $\left(\mathrm{H}_{1}\right)$ is accepted and indicated there is a significant difference in vocabulary size between students who participated in English debate competition and those who did not participate, while the null hypothesis $\left(\mathrm{H}_{0}\right)$ was automatically rejected.
\end{abstract}

Keywords : Debate Competition, Vocabulary Size 


\section{Introduction}

As the first priorities, words, or the vocabulary must be put as the root of the tree after all, but the fact that vocabulary either learning or teaching is put in the different part of the tree means that the existence of vocabulary is still underrated. It is a common knowledge that without vocabulary, we can not learn everything about language. Wilkins (1987) says that "Without grammar very little can be conveyed, without vocabulary nothing can be conveyed" (p.135). According to Aclan and Aziz (2014), the students need to be given such a contextualized, challenging and meaningful way to learn new vocabulary, and debate is the communicative activity that can be done by the teacher in the classroom. This communicative activity encourages students to find the new vocabularies in context and particular topics according to what they are going to debate. After finding the communicative strategy to teach and learn vocabulary for both of the teacher and the students, we know that by this strategy, the students may improve their vocabularies and it also means that they may improve their vocabulary size.

Debate activity is mostly known as a competition rather than a common method that usually applied by the teacher in the classroom to increase the students vocabulary. For instance, senior high school in Indonesia usually provides an English club for the students to make them prepare in joining English debate competition (Aclan \& Aziz 2014). The latest study about the correlation between debate activity and vocabulary was conducted because there is no study about it previously. And in this case, there are just a few studies that show the relationship between joining debate competition and the vocabulary size, whether the students who participated in English debate competition will have the higher vocabulary size rather than the students who did not participate, or in contrast, the students who did not participate in English debate competition will have the higher vocabulary size rather than the students who participated.

Based on the background of the study, the research question of this research was "Is there any significant difference in vocabulary size between 
students who participated in debate competition and those who did not participate in debate competition?"

\section{Literature Review}

Nation (1990) as cited in Waring and Nation (1997) reveals that to use English effectively, all of the English learners need to know approximately 2000 to 3000 words level. He found that $87 \%$ words in the text was coming from the basic of 2000 frequent word. Laufer (1998) as cited in Zimmerman (2004) also supported Nation's statement by suggesting that it is very important to know 3000 word level to comprehend a text since he found that learners with vocabulary size below 3000 word level is quite difficult to understand the text. From these keys, we could find that the second level (2000) and third level (3000) of vocabulary size is the most important level that students need to know in order to understand and comprehend a text. The next study showed that, by using British National Corpus data, the second language learners need about 8000 - 9000 word families to read novel or newspaper (Nation, 2006, as cited in Bayazidi, 2017). "Debating is the ultimate multi-task activity since it involves research, writing, speaking, listening, and teamwork" (Allison, 2002 as cited in Zare \& Othman, 2015). If we could think about the causal effect, we must be thought that there would not be such activities if we have no idea about what we want to talk about. We do not know the meaning of the words when we do research, we do not know the proper words to write, we don't have any vocabularies to say in speaking activity, and so on.

Based on the study conducted by Aclan and Aziz (2014) showed that the students are literally doing research by themselves to find the data of the topic being debated. By this research, they will read and hear anything that relates to the topic. In this case, we can assume that their time to read will affect their vocabulary size. They also will make notes and speak using the words that they find, and it will affect their long term-memory to save the vocabularies in their brain. 


\section{Methods}

This research used Ex post facto design in which two groups were compared, both of the groups were different, the first group is the group of students that participated in English debate competition, and the second group is those who did not participate in English debate competition. The first group can not be manipulated since the students had done the competition and the treatment had been experienced by the students by training to improve their speaking ability, and public speaking to improve their confidence, and those things were done to prepare the students join the competition, while the second group did not get any treatment. The participants of this research were 30 students from three different schools, they were SMAN 2 Kendari, SMAN 4 Kendari, and SMAN 5

Kendari.

This research used the New Vocabulary Size Test by Stuart McLean and Brandon Kramer in 2015 is the 4.5 version. The target words of the NVLT come from Nation's (2012) British National Corpus (BNC)/Corpus of Contemporary American English (COCA) word lists. This test consists of 24 items test for every level of 1000 words and the total is 120 until the level of 5000, as an addition is 30 items for AWL (Academic Word List). The data were taken by using the test, and analyzed by using descriptive analysis to see the mean, standard deviation, maximum and minimum score, and then used the inferential statistic to test the hypothesis.

\section{Findings and Discussion}

This research had been done in three schools, they were SMAN 2 Kendari, SMAN 4 Kendari, and SMAN 5 Kendari. The students in each school had been divided into two groups. The first group was the group of students who had participated in English debate competition, while the second group was the group in which the students had never joined English debate competition. As can be seen in the test result, the higher mean score was gained by the first group with the mean of the test that can be answered was 104 correct answer, and the mean of vocabulary size that students got was 3473 and the total percentage was $69 \%$. 
While the second group got lower mean score than the first group, the mean score of the question that students could answer was 82, and the mean of their vocabulary size was 2733 with the total percentage was 55\%. The percentage showed that both of the groups were still could not answer all of the questions to get $100 \%$.

The standard deviation between the groups was different, where the first group got 13.929 while the second group got 17.704. The standard deviation showed the positive square root of the variance. In standard deviation, if the scores are more tightly clustered around the mean, the standard deviation will be smaller, while, if they are spread out further from the mean, the standard deviation will be larger (Larson-Hall, 2010). The values of the standard deviation for both group of students were quite big, which interpreted that the data were out further from the mean. But, the value of the standard deviation of the first group was lower than the second group. It indicated that the data from group one were more tightly clustered around the mean, or it can be said that it was more homogeneous than the data from group two.

The analysis of the data had shown that the data were homogeneous and distributed normally with both of the value were higher than alpha value (0.05). Based on that result, the data then examined to know the result of the hypothesis testing. Independent sample t-test was used to do the hypothesis testing since the independent-samples t-test assumes that the two mean scores are independent of each other and the groups of the students consist of different people. And also, since the data variances were equal, thus the result of the hypothesis testing would be seen from the result in sig.two-tailed. Sig.two-tailed itself was used when there were two things tested. Just such this research where two groups of students, the first group was the group of students who participated in English debate competition, and the second group was the group of students who did not particpate in English debate competition, both of the groups were tested to see whether there was a significant difference based on the result. The result of the t- test showed that the null hypothesis was rejected, and the alternative hypothesis was accepted with the value of 0.001 ( $\mathrm{sig}$. $<0.005$ ). In brief, there is a significant 
difference in the vocabulary size between students who participated and those who did not participate in English debate competition where the result showed that the students who participated in English debate competition had the higher vocabulary size than the students who did not participate in English debate competition.

\section{Conclusion}

The result of this research showed that there is a significant difference in vocabulary size between the students who participated and those who did not participate in English debate competition. The alternative hypothesis $\left(\mathrm{H}_{1}\right)$ was accepted, and null hypothesis $\left(\mathrm{H}_{0}\right)$ was rejected. In brief, the students who participated in English debate competition have the higher vocabulary size than those who did not participate in English debate competition.

\section{References}

Aclan , E., \& Abd. Aziz, N. (2014). Why and How EFL Students Learn Vocabulary in Parliamentary Debate Class, 4(2), 1-16. 10.7575/aiac.ijalel.v.4n.2p.1.

Bauer, L., \& Nation, I.S.P. (1993). Word families. International Journal of Lexicography. 6(4), 253-279. Retrieved from http://www.robwaring.org/papers/CUP/cup.html, March, 13 ${ }^{\text {th }}, 2018$.

Bayazidi, A., \& Saeb, M. (2016). Assessing Reliability of Two Versions of Vocabulary Levels Tests in Iranian Context: Advances in Language and Literary Studies, 8(1), Doi:10.7575/aiac.alls.v.8n.1p.30.

Biemiller, A. (2005). Size and sequence in vocabulary development. In E. H. Hiebert \& M. L. Kamil (Eds.), Teaching and Learning Vocabulary. Bringing Research into Practice, p. 223-242. Mahwah, N.J.: Lawrence Erlbaum Associates.

Branham, R., \& Meany, J. (1998). Debating Resources for the World since 1994: Parliamentary debate. Retrieved from https://debate.uvm.edu/meanyparli.html, March, $8^{\text {th }}, 2018$.

Brown, H. D. (2001). Teaching by principles: An interactive approach to language pedagogy. USA: Longman. 
Cameron, L. (2002). Measuring vocabulary size in English as an additional language.Language Teaching Research 6(2), p. 145-173. Retrieved from http://journals.sagepub.com/doi/10.1191/13621688021r103oa.

Coxhead A, Nation P, \& Sim D. (2015). Measuring the Vocabulary Size of Native Speakers of English in New Zealand Secondary Schools New Zealand Journal of Educational Studies. 50: 121-135. DOI: 10.1007/s40841-0150002-3

D'anna, C.A., Zechmesiter, E.B., \& Hall, J.W. (1991). Toward A Meaningful Definition of Vocabulary Size. Journal of Reading Behavior, 23(1).

DiMinichi, B. C., \& Tricomi, E. (2015). The power of competition: Effects of social motivation on attention, sustained physical effort, and learning, retrieved from https://doi.org/10.3389/fpsyg.2015.01282, July, $3^{\text {rd }}, 2018$.

Goulden, R., Nation, I.S.P. and Read, J. (1990) How large can a receptive vocabulary be? Applied Linguistics 11, 4: 341-363.

Larson-Hall, J. (2010). A Guide to Doing Statistics in Second Language Research Using SPSS. New York: Taylor \& Francis.

Laufer, B. \& Nation, P. (1999). A productive-size test of controlled productive ability. Language Testing, 16 (1), 33-51.

Liu, N., \& Nation, I.S.P. (1985). Factors affecting guessing vocabulary in context. RELC Journal 16(1), p. 33-42.

Lomangino, H. (1986). Knowledge of vocabulary and reading comprehension: An important relationship. Pacific Northwest Conference on Foreign Languages, Vancouver. (ERIC Document Reproduction Service No. ED 277283)

Lorge, I., \& Chall, J. (1963). Estimating the size of vocabularies of children and adults: an analysis of methodological issues. Journal of Experimental Education, 32(2), 147-157.

McLean, S., \& Kramer, B. (2015). The creation of a New Vocabulary Levels Test. Shiken 19(2), p. 1-11. Retrieved from http://teval.jalt.org/node/33, March, $16^{\text {th }}, 2018$.

Nacera, A. (2010). Languages learning strategies and the vocabulary size. Procedia Social and Behavioral Sciences 2, p. 4021-4025, doi:10.1016/j.sbspro.2010.03.634. Retrieved from 
https://www.sciencedirect.com/science/article/pii/S1877042810006749, June, $12^{\text {nd }}, 2018$.

Nation, P. (1990) Teaching and Learning Vocabulary New York: Newbury House,.retrieved from https://escholarship.org/uc/item/6xc5z4dq, March, $16^{\text {th }}, 2018$.

Nation, P. (2006). How large a vocabulary is needed for reading and listening? The Canadian Modern Language Review, 63(1), 59-82. doi: 10.3138/cmlr.63.1.59

Nation, P., \& Waring, R. (1997) Vocabulary size, text coverage, and word lists: Vocabulary: Description, Acquisition and Pedagogy N. Schmitt and M. McCarthy (eds.). Cambridge University Press, Cambridge: 6-19.

Nebbe, D.E. (1999). Vocabulary size and GPA for non-native speakers of English: Retrospective Theses and Dissertations, 16148. Retrieved from https://lib.dr.iastate.edu/cgi/viewcontent.cgi?referer=https://www.google.co. id/\&httpsredir=1\&article=17147\&context=rtd, March, 13th 2018.

Ozturk, M.A., \& Debelak, C. (2008). Affective Benefits From Academic Competitions for Middle School Gifted Students. 31 (2). Retrieved from https://files.eric.ed.gov/fulltext/EJ789919.pdf, July, $3^{\text {rd }}, 2018$.

Richards J. C. \& Renandya, W. A. (2002). Methodology in language teaching: An anthology of current practice, p. 254-266. Cambridge: Cambridge University Press

Scmitt, N., \& Mccarthy, M. (1997). Vocabulary: Description, Acquisition, and Pedagogy. United Kingdom: The Press Syndicate of The University of Cambridge.

Webb, S., \& Sasao, Y. (2013). New Direction in Vocabulary Testing. RELC Journal 44(3), p. $263 \quad-277, \quad$ DOI: $10.1177 / 0033688213500582$ rel.sagepub.com

Wilkins, D. (1987). Linguistics in language teaching. London: Edward Arnold.

Zare, P. \& Othman, M. (2015). Students' Perceptions toward Using Classroom Debate to Develop Critical Thinking and Oral Communication Ability. Asian Social Science, 11 (9), 158-170, doi:10.5539/ass.v11n9p158. 
Zimmerman, K. J. (2004). The Role of Vocabulary Size in Assessing Second Language Vocabulary. All Theses and Dissertations. Retrieved from http://scholarsarchive.byu.edu/etd/578, December, $24^{\text {th }}, 2017$. 